\title{
The 15th National Conference for Health can make a difference
}

A consensus spreads out in Brazil regarding the weariness and safety of conferences as capacity of this instance of participatory democracy being able to produce and present effective proposals for the necessary changes in the course of health in the country. The reasons are complex and cover from the fragmentation of proposals to the contempt of many managers for the results of these conferences that, in most of the cases, do not take into consideration the recommendations and guidelines issued in the definition of the respective private health insurances. This time it can be different, for not only does the process of pre-conferences include innovations that allow new alternatives of participation to the debate, but also the National Health Council has programmed the monitoring of the implementation of its results.

Cebes trusts in the results of the national mobilization around the 15th National Conference for Health to propel and magnify society's politicization concerning the universal right to health and the duty of the Estate. Aiming to contribute with the debates, it reaffirms proposals synthesized in the sentence 'Health is not merchandise, it is right to citizenship', grounding the thesis from the entity to the 15th Conference, whose main points are here registered:

Social Rights, in order to be guaranteed by social policies, are expensive. The 15th National Conference for Health (CNS) must make clear who should pay the costs of social policies that ensure rights. For that, this debate should start in city conferences, state conferences, plenaries, and all the spaces of debate in health. The funding of social policies can not penalize even more the working classes that, proportionally, pay more taxes.

The conjuncture demands a steady and articulated political action from all those who defend SUS and the right to health, under the risk of hosting the first moment of regression in the positive rights constitutionally guaranteed since the country's re-democratization. Before such conjuncture, we defend the following proposals:

1) Advance in social development, with progressive raise of the federal expenses with social policies on health, education and social assistance;

2) Perform auditing of public debt and increase the investment as lever for economic growth, reducing interest and not giving in to cambial pressure and that of balance of payment;

3) Perform political reform that deepens and improves participative democracy, with the establishing of new institutional rules that ensure the extension of democratic participation and the end of business financing of election campaigns and the interference of economic power in politics;

4) Perform tax reform that sets Brazil on the direction of countries that have achieved fairer tax systems by reducing the taxation on consumption and concentrating it on patrimony and income. For that, it is necessary: to improve the distribution of income tax rates for individuals with higher tax ranges and extension of exemption range; reduce indirect taxation on consumption; increase taxation on accumulation; increase the Imposto sobre a Propriedade Territorial Rural (ITR) (Tax on Rural Property) of large land properties; reduce the taxes that 
focus directly on the productive sector (Imposto sobre Produtos Industrializados - IPI) and Imposto sobre Circulação de Mercadorias e Serviços - ICMS) (Tax on Industrialized products and Tax on Goods and Services); end the exemption of profits and dividends and with the deduction of interest on own capital and alleviate the tax burden of workers with progressive tax;

5) Democratize the media to guarantee the right to information and reduce the filter power that preserves the interest of specific groups of owners, in addition to expanding alternatives to the media;

6) Face the inequalities and iniquities in health and consolidate the constitutional SUS. For that, it is necessary to:

- End private health insurance subsidy through progressive strategy, initially instituting a limit to health expenses, which can be deductible from income taxes, like in case of education, for instance; not finance private health insurance for federal employees with federal resources; prohibit debt relief or cancellation from private insurances with the State; prohibit direct subsidy to health insurance and not promote incentives to private health insurances.

- Apply resources resulted from the subsidies especially in primary health care (Family Health Strategy, promotion and prevention to health) and in medium complexity (specialized care with professionals and suited technological resources of diagnostic and therapeutic support).

- Tax great fortunes to apply the resources in health. The greatest 15 Brazilian fortunes belong to huge companies that exercise the monopoly of communication, like Rede Globo and Grupo Abril, of agribusiness and banks like Safra, Itaú, and Bradesco. Such collection corresponds to almost the entire volume of resources that the government will collect with the latest changes on taxation.

- Prevent regression in the right to health. Stop projects currently underway in the National Congress that act against SUS, for example the project of Constitutional Amendment 451, authored by Eduardo Cunha, which intends to alter the Constitution and make private health insurance mandatory to working employees.

- Guarantee larger public financing with the end of Exemption of Union Revenues (Desoneração das Receitas da União - DRU) to the health sector; relax the Fiscal responsibility Law (Lei de Responsabilidade Fiscal - LRF) for the contracting of health workers (investing in the board of proper servers in health and reducing the hiring of Social Organizations) and invest $10 \%$ of the Current Gross Revenue in public health.

- Consolidate SUS as a unique and universal system, with stable state financing and public administration which guarantees the integral offer of services and care of quality.

- Report and repudiate the false proposal of Universal Health Coverage, which does not provide coverage to all, but limited packages of services that do not meet the population's need for health. 
Cebes ends this Thesis for the 15th CNS, reaffirming that there will not be 'Quality public health to take good care of people' without the consolidation of SUS and with a health system ruled by the market and guided by the private offer of services, as it has been being recommended and insinuated by sectors of society and the State itself, which defend a liberal development project.

With the intention of contributing to such debate, in a time of extreme risk of regression concerning the right to health and the SUS, Cebes presents this thesis and calls social movements, users, workers, managers, and mobilized groups for the process of the 15th CNS to unite in defense of $S U S$ and politically debate the health project which is underway and the one which we want for Brazil (CEBES, 2015).

\section{Ana Maria Costa}

Centro Brasileiro de Estudos de Saúde (Cebes) National Board. Escola Superior de Ciências da Saúde (ESCS) - Brasília (DF), Brasil. Associação Latino-Americana de Medicina Social (Alames). dotorana@gmail.com

Maria Lucia Frizon Rizzotto

Centro Brasileiro de Estudos de Saúde (Cebes) National Board. Universidade Estadual do Oeste do Paraná (Unioeste) - Cascavel (PR), Brasil.

frizon@terra.com.br

\section{References}

CENTRO BRASILEIRO DE ESTUDOS DE SAÚDE (CEBES). Tese para a $15^{a}$ Conferência Nacional de Saúde. [2015]. Available in: <http://cebes.org.br/site/
wp-content/uploads/2015/04/Tese-Cebes-15-CNS_ Final_1704.pdf >. Access: 19 jun. 2015. 